\title{
Insulinotropin: Glucagon-like Peptide I (7-37) Co-encoded in the Glucagon Gene Is a Potent Stimulator of Insulin Release in the Perfused Rat Pancreas
}

\author{
Svetlana Mojsov," Gordon C. Weir, ${ }^{\ddagger}$ and Joel F. Habener* \\ *Laboratory of Molecular Endocrinology, Massachusetts General Hospital and Howard Hughes Medical Institute, Harvard Medical \\ School, Boston, Massachusetts 02114; and ${ }^{\ddagger}$ Joslin Diabetes Center and New England Deaconess Hospital, and Harvard Medical School, \\ Boston, Massachusetts 02115
}

\begin{abstract}
Insulin secretion is controlled by a complex set of factors that include not only glucose but amino acids, catecholamines, and intestinal hormones. We report that a novel glucagon-like peptide, co-encoded with glucagon in the glucagon gene is a potent insulinotropic factor. The glucagon gene encodes a proglucagon that contains in its sequence glucagon and additional glucagonlike peptides (GLPs). These GLPs are liberated from proglucagon in both the pancreas and intestines. GLP-I exists in at least two forms: 37 amino acids GLP-I(1-37), and 31 amino acids, GLP-I(7-37). We studied the effects of synthetic GLP-Is on insulin secretion in the isolated perfused rat pancreas. In the presence of $6.6 \mathrm{mM}$ glucose, GLP-I(7-37) is a potent stimulator of insulin secretion at concentrations as low as $5 \times 10^{-11} \mathrm{M}$ (3to 10-fold increases over basal). GLP-I(1-37) had no effect on insulin secretion even at concentrations as high as $5 \times 10^{-7} \mathrm{M}$. The earlier demonstration of specific liberation of GLP-I(7-37) in the intestine and pancreas, and the magnitude of the insulinotropic effect at such low concentrations, suggest that GLPI(7-37) participates in the physiological regulation of insulin secretion.
\end{abstract}

\section{Introduction}

Pancreatic glucagon and intestinal glicentin are synthesized in the form of a 180-residue protein, preproglucagon encoded in a single gene (1). The precursor contains in addition to glicentin and glucagon the sequences of two glucagon-like peptides (GLPs) ${ }^{1}$, GLP-I and GLP-II, separated by an intervening peptide (IP-II) (2-5). The posttranslational processing of preproglucagon differs in pancreas and intestine $(1,6)$. In the pancreas the precursor is processed to glucagon and GLP-I, and in both large and small intestines glicentin, GLP-I, GLP-II and IP-II-leucineamide are found. Both pancreas and intestine contain GLP-I in at least two forms -31 and 37 residues long (1).

The close similarity of the amino acid sequence of GLP-Is and GLP-II with glucagon and the other peptides related in structure to glucagon (secretin, vasoactive intestinal peptide, gastric inhibitory peptide, growth hormone-releasing hormone)

Received for publication 28 October 1986.

1. Abbreviation used in this paper: GLP, glucagon-like peptide.

J. Clin. Invest.

(C) The American Society for Clinical Investigation, Inc.

0021-9738/87/02/0616/04 \$1.00

Volume 79, February 1987, 616-619 suggests that the GLPs might have a role in metabolic regulation. The specific liberation of GLP-I and GLP-II in the intestine indicates that these peptides may be components of the enteroinsular axis (7), which comprises multiple intestinal factors influencing the release of hormones produced in the pancreatic islets. Further, they may be incretins, endocrine transmitters produced in the gastrointestinal tract that are released by nutrients and stimulate insulin secretion in the presence of elevated glucose if exogeneously infused in amounts not exceeding blood levels achieved after food ingestion (8). Detection of both GLPI(1-37) and GLP-I(7-37) in pancreas and intestines raises the possibility that GLP-I(1-37) is itself a prohormone that undergoes a proteolytic cleavage at the single arginine residue at position 6 to release the biologically active GLP-I(7-37). In these studies we used synthetic GLP-I(1-37) and GLP-I(7-37) to investigate their effects on insulin secretion in the perfused rat pancreas and find that GLP-I(7-37) has uniquely potent insulinotropic actions.

\section{Methods}

Synthesis of peptides. Glucagon and GLP-Is were synthesized by the stepwise solid-phase method (9). Because the assembly of the peptide chain proceeds in the carboxyl- to the amino-terminal direction, GLPI(1-37) and GLP-I(7-37) were prepared in the same synthesis by separating the peptide resin after incorporation of a protected histidyl residue at position 7 and continuing the assembly of amino acids on the other aliquot of the peptide resin to obtain protected GLP-I(1-37) peptide resin. Peptides were purified by preparative reverse-phase $\mathrm{C}-18$ chromatography. Purified peptides were shown to be homogeneous by amino acid analysis, preview-sequence analysis, and high performance liquid chromatography (HPLC) on reverse-phase C-18 and ion-exchange DEAE-52 columns.

Radioimmunoassays. Development of the antisera and competitive binding radioimmunoassays for glucagon and GLP-I are described elsewhere (1). In brief, samples were incubated with the antisera in borate buffer ( $\mathrm{pH} 8.1$ ) for $24 \mathrm{~h}$ at $0^{\circ} \mathrm{C}$, followed by addition of ${ }^{125}$ I-labeled peptide for an additional $24 \mathrm{~h}$ in a total volume of $0.5 \mathrm{ml}$. Separation of the antibody bound from the free peptide was accomplished with dextran-coated charcoal. Assay sensitivity with all three antisera was 10 $\mathrm{pg} / \mathrm{ml}$. The antiserum against GLP-I was obtained by immunization with GLP-I(1-37) and is directed against both the amino-terminal (1-6) part of the molecule and to 7-37 determinants. Therefore, the amount of GLP-I(7-37) may be over or underestimated with respect to GLP-I(137 ) in the assay. The assay for insulin (10) used charcoal separation and rat insulin standards (Novo Research Institute, Copenhagen, Denmark).

Rat-perfused pancreas experiments. The preparation of the in situ isolated rat pancreas has been described previously $(11,12)$. The perfusate contained bicarbonate buffer ( $\mathrm{pH} 7.4$ ) and $120 \mathrm{mg} / \mathrm{dl}$ glucose, $4 \%$ dextran $\mathrm{T}-70$, and $0.2 \%$ bovine serum albumin, and was equilibrated with $95 \%$ $\mathrm{O}_{2}$ and $5 \% \mathrm{CO}_{2}$. The first 20 min of each perfusion was an equilibration period and is not represented in the data graphs. 
After the initial 20-min equilibration period, aliquots of perfusate were removed every 2-4 min for additional $20 \mathrm{~min}$, thus allowing the system to equilibrate for a total of $\mathbf{4 0} \mathrm{min}$. The perfusion, with GLPI(1-37) or GLP-I(7-37), was for 6 min and samples were collected at 1min intervals. The peptide perfusions were followed by equilibration periods of $20 \mathrm{~min}$, during which four samples $5 \mathrm{~min}$ apart were collected. A second 6-min perfusion followed with the same peptide as the first perfusion only at 100 times higher concentration of peptide. Again, samples 1 min apart were collected. The entire perfusion time was between 70 and $85 \mathrm{~min}$.

In each aliquot of perfusate obtained, insulin was determined by radioimmunoassay. In addition the efficiency of delivery of the GLP-Is was confirmed by radioimmunoassay of corresponding aliquots of perfusate in which insulin was measured (1).

\section{Results}

To optimally study the effects of GLP-I(7-37) and GLP-I(1-37) on insulin secretion we used separate perfusions with each peptide, perfusing twice at two different concentrations of peptides and allowing 20-min time intervals between the two perfusions. In perfusions of two separate pancreases using this protocol, GLP-I(7-37) was a potent stimulator of insulin secretion, giving about a 20 -fold stimulation at $5 \times 10^{-9} \mathrm{M}$ and a sixfold stimulation at $5 \times 10^{-11} \mathrm{M}$ (Fig. 1). In comparison, GLP-I(1-37), also studied in two pancreases, showed no effect on insulin secretion at either $5 \times 10^{-9}$ or $5 \times 10^{-7} \mathrm{M}$ (Fig. 2). At the latter concentration no effect was observed even during a 15 -min perfusion period (Fig. $2 \mathrm{~B}$ ).

Using a slightly different perfusion protocol than that described above (Figs. 1 and 2 ) we gave alternate 5 -min infusions of the peptides at concentrations ranging from $5 \times 10^{-7}$ to 5 $\times 10^{-12} \mathrm{M}$ to five additional individual pancreases. We reproducibly observed insulin release in response to GLP-I(7-37) at concentrations as low as $5 \times 10^{-11} \mathrm{M}$, and little if any insulin responses to GLP-I(1-37) at concentrations as high as $5 \times 10^{-7}$ M. Thus, the potent insulinotropic actions of GLP-I(7-37) have been observed in studies of seven separate pancreases.

Effects of glucagon on insulin secretion in the perfused pancreas have been established previously (13). We also compared the effects of glucagon to that of the GLP-Is. We used synthetic glucagon in the concentration range of $10^{-11}-10^{-7} \mathrm{M}$ and found it to be less potent than GLP-I(7-37).

\section{Discussion}

The results of these studies clearly indicate that GLP-I(7-37) has potent insulinotropin activity. The liberation of this peptide from proglucagon in the intestine, and to a lesser extent in the pancreas (1), raises the possibility that GLP-I(7-37) has a role in endocrine regulation in the entero-insular axis (7). Our data, taken together with earlier observations that glucagon-like immunoreactivity in crude gut extracts released insulin after ingestion of glucose and fat, (8) suggest that GLP-I(7-37) could potentially be an incretin. Of all the known intestinal hormones tested for their insulin-releasing potency in the past, gastric inhibitory peptide has been considered as a possible incretin $(14,15)$. However, the concentrations of gastric inhibitory peptide required to stimulate insulin secretion exceed the physiologic levels of the peptide achieved after a meal. In the rat-perfused pancreas in the presence of $8.9 \mathrm{mM}$ glucose, gastric inhibitory peptide $\left(10^{-9} \mathrm{M}\right)$ increased insulin secretion sixfold (16). We find a comparable increase in insulin secretion with GLP-I(7-37) at concentrations 100 -fold lower than those required for an insulinotropic response to gastric inhibitory peptide. By radioimmunoassay we have measured both GLP-I(1-37) and GLP-I(7-37) levels of $\sim 150 \mathrm{pg} / \mathrm{ml}(50$ $\mathrm{pM})$ in rat portal blood and $50 \mathrm{pg} / \mathrm{ml}(15 \mathrm{pM})$ in peripheral blood (S. Mojsov, unpublished results). Therefore, the insulinotropic effect that we have observed at concentrations of GLPI(7-37) of between 5 and $50 \mathrm{pM}$ are well within the physiological levels of GLP-I(7-37) found in the circulation.

There has been considerable interest in the potential intraislet relationships which might occur between $A, B$, and D cells, such that the secretory product of one cell type might influence the function of a neighboring cell (17). Interaction could take place via a paracrine mechanism or through a local intra-islet portal system. Glucagon can stimulate both insulin and somatostatin secretion $(13,18)$, but because there appears to be a functional compartmentalization between islet cells, it is unclear whether glucagon can actually reach B and D cells (19). Taking into account the vascular arrangement of the rat islet, the glu-

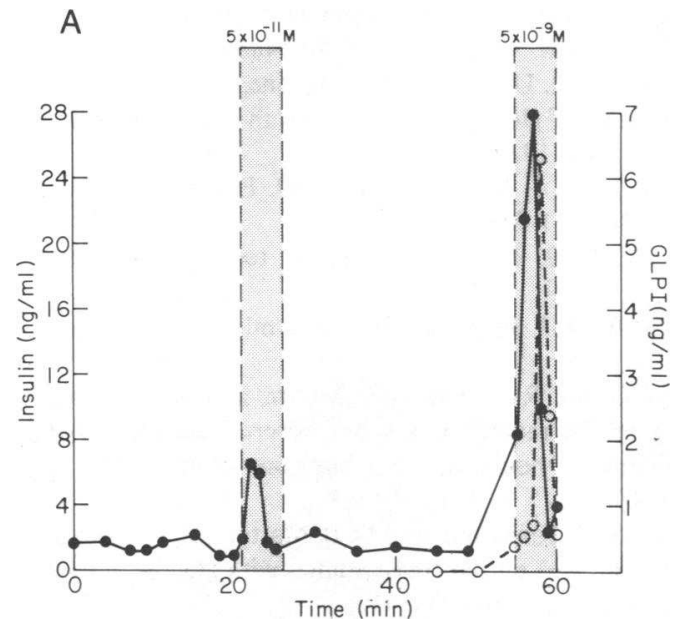

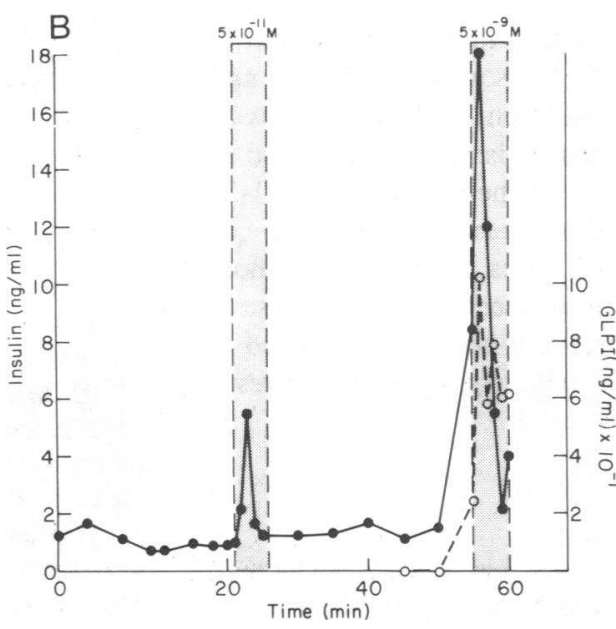

Figure 1. The effects of separate perfusions in two representative pancreas GLP-I(7-37) at two concentrations, $5 \times 10^{-11}$ and $5 \times 10^{-9} \mathrm{M}$. Solid lines, insulin values determined by radioimmunoassay. Dashed lines, amount of peptide perfused as determined in a competitive binding radioimmunoassay with antisera against GLP-I(1-37). The amount of GLP-I(7-37) at $5 \times 10^{-11} \mathrm{M}$ is beyond the detection sensitivity of the radioimmunoassay. Each graph represents a perfusion of a separate pancreas with a given peptide. 

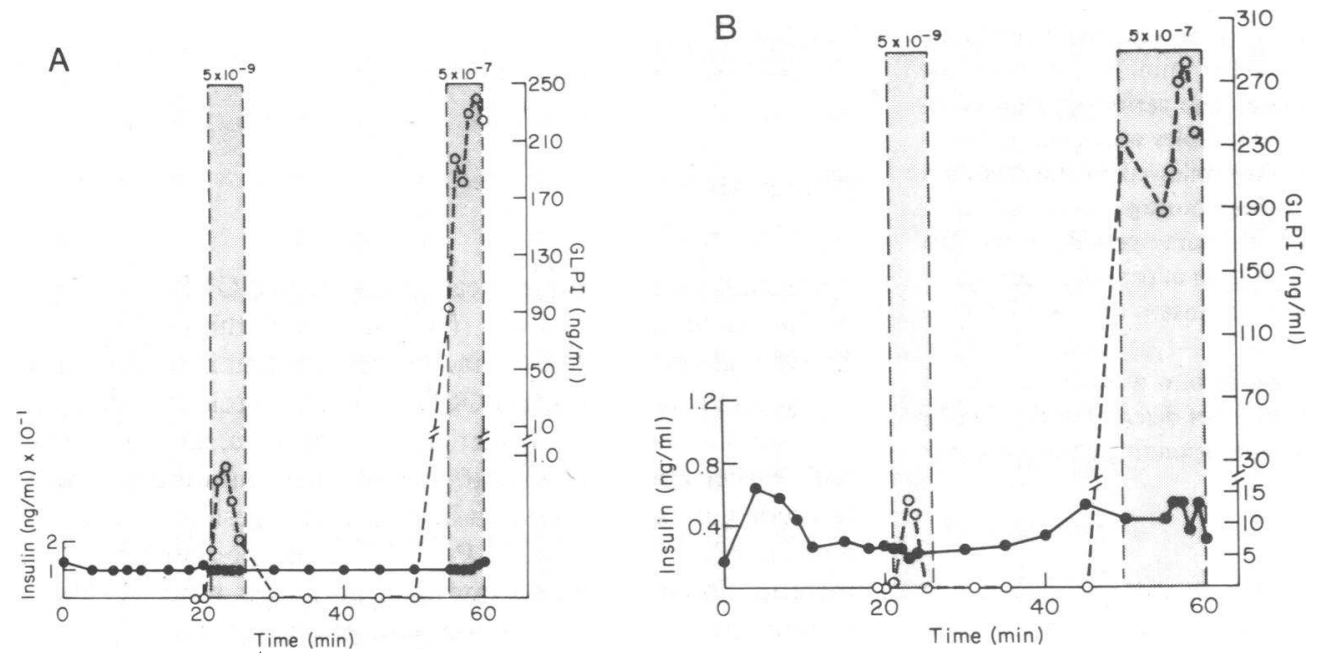

Figure 2. The effects of separate perfusions in two representative pancreas with GLP-I(1-37) at two concentrations, $5 \times 10^{-9}$ and $5 \times 10^{-7} \mathrm{M}$. Details of the experiment and explanation of symbols are described in legend to Fig. 1. cagon-containing A cells of the mantle appear to be downstream from the B cells of the core, and therefore glucagon may not reach the $B$ cells in high enough concentration to exert a significant influence (20). The mantle of $A$ and $D$ cells are, however, adjacent and this makes the possibility of paracrine interaction more feasible, although experimental support for such an interaction is not available. The finding that GLP-I(7-37) is a more potent insulin secretagogue than glucagon raises important questions about its potential intra-islet role.

Amino and carboxyl-termini of glucagon, GLP-I(7-37) and GLP-II are closely related to each other in their amino acid sequences and to vasointestinal peptide that possibly exerts a neuronal stimulation of insulin secretion (21). A most striking similarity among them is the conservation of a histidine residue at position 1 . It is noteworthy that gastric inhibitory peptide, also closely related in its structure to the GLPs, has a tyrosine residue at position 1 instead of histidine (22). Inasmuch as a histidine residue at this position is essential for adenylate cyclase stimulation in various systems, the greater insulinotropic potency of GLP-I(7-37) compared with GIP may in part be accounted for by the histidine substitution for tyrosine (23).

Additional evidence in support of the concept that GLP-I(737 ) is a potent insulinotropic peptide is provided by our recent observation that GLP-I(7-37), and not GLP-I(1-37) or GLP-II, is a potent activator of adenylate cyclase at concentrations as low as $5 \times 10^{-11} \mathrm{M}$ and also stimulates cellular levels of insulin mRNA and insulin release in a rat insulinoma cell line (RIN38) (Drucker, D. J., J. Philippe, S. Mojsov, W. L. Chick, and J. F. Habener, manuscript in preparation). Further, studies by Schmidt and co-workers showed that in isolated precultured islets, $10^{-9}$ to $10^{-8} \mathrm{M}$ concentrations of the peptide GLP-I(1-36 des Gly-Arg amide) were required to release insulin (24).

Determining whether GLP-I(7-37) is the hormone whose primary function is to stimulate insulin secretion in response to feeding, or is one of a complex group of hormones involved in maintaining glucose homeostasis, will require further investigation.

\section{Acknowledgments}

We thank Henrietta Cooper, Deanna Deery, and Adacie Allen for their expert experimental assistance in carrying out the pancreatic perfusions and radioimmunoassay, respectively. We thank Esther Hoomis for typing the manuscript.

The studies were supported in part by Public Health Service grants AM 30834 and AM 20349.

Note added in proof. In studies of isolated perfused pig ileum and pancreas, Orskov et al. (25) recently reported finding secretion of a GLP-1 peptide from ileum, but the pancreas secreted a large peptide with both GLP-1 and GLP-2 immunoreactivity.

\section{References}

1. Mojsov, S., G. Heinrich, I. B. Wilson, M. Ravazzola, L. Orci, and J. F. Habener. 1986. Preproglucagon gene expression in pancreas and intestine diversifies at the level of post-transcriptional processing. J. Biol. Chem. 261:11880-11889.

2. Heinrich, G., P. Gros, and J. F. Habener. 1984. Glucagon gene sequence: four of six exons encode separate functional domains of rat preproglucagon. J. Biol. Chem. 259:14082-14084.

3. Bell, G. I., R. F. Santerre, and G. T. Mullenbach. 1983. Hamster preproglucagon contains the sequence of glucagon and two related peptides. Nature (Lond.). 302:716-718.

4. Bell, G. I., R. Sanchez-Pescador, P. J. Laybourn, and R. C. Najarian. 1983. Exon duplication and divergence in the human preproglucagon gene. Nature (Lond.). 304:368-371.

5. Lopez, L. C., M. L. Frazier, C. J. Su, A. Humar, and G. F. Sanders. 1983. Mammalian pancreatic preproglucagon contains three glucagonrelated peptides. Proc. Natl. Acad. Sci. USA. 80:5485-5489.

6. George, S. K., L. D. Uttenthal, M. Ghiglione, and S. R. Bloom. 1985. Molecular forms of glucagon-like peptides in man. FEBS (Fed. Eur. Biochem. Soc.) Lett. 192:275-278.

7. Unger, R. H., and A. M. Eisentraut. 1969. Entero-insular axis. Arch. Intern. Med. 123:261-266.

8. Creutzfelt, W. 1979. The incretin concept today. Diabetologia. 16:75-85.

9. Merrifield, R. B. 1963. Solid phase peptide synthesis. J. Am. Chem. Soc. 95:2149-2154.

10. Albano, J. D. M., R. P. Ekins, G. Maritz, and R. C. Turner. 1972. A sensitive, precise radioimmunoassay of serum insulin, relying on charcoal separation of bound and free hormone moities. Acta Endocrinol. 70:487-509.

11. Weir, G. C., S. D. Knowlton, and D. B. Martin. 1974. Glucagon secretion from the perfused rat pancreas. Studies with glucose and catecholamines. J. Clin. Invest. 54:1403-1412. 
12. Penkos, J. C., C.-H. Wu, J. C. Basabe, N. Lopez, and F. W. Wolf. 1969. A rat pancreas-small gut preparation for the study of intestinal factor(s) and insulin release. Diabetes. 18:733-738.

13. Samols, E., G. Marri, and V. Marks. 1966. Interrelationship of glucagon, insulin, and glucose: the insulinogenic effect of glucagon. $\mathrm{Di}$ abetes. 15:855-865.

14. Dupre, J., S. A. Ross, D. Watson, and J. C. Brown. 1973. Stimulation of insulin secretion by gastric inhibitory polypeptide in man. $J$. Clin. Endocrinol. Metab. 37:826-828.

15. Andersen, D. K., D. Elahi, J. C. Brown, J. D. Tobin, and R. Andres. 1978. Oral glucose augmentation of insulin secretion. Interactions of gastric inhibitory polypeptide with ambient glucose and insulin levels. J. Clin. Invest. 62:152-161.

16. Brown, J. C., and R. A. Federson. 1976. The insulinotropic action of gastric inhibitory polypeptide in the perfused isolated rat pancreas. Endocrinology. 99:780-785.

17. Samols, E., G. C. Weir, and S. Bonner-Weir. 1983. Intraislet insulin-glucagon-somatostatin relationships. In P. J. Lefebvre, editor. Handbook of Experimental Pharmacology. Vol. 66. Springer-Verlag, Berlin. 133-173.

18. Unger, R. H., and L. Orci. 1977. Hypothesis: the possible role of the pancreatic D-cell in the normal and diabetic states. Diabetes. 26 : 241-244.
19. Kawai, K., E. Ipp, L. Orci, A. Pezzelet, and R. H. Unger. 1982. Circulating somatostatin acts on the islets of Langerhans by way of somatostatin-poor compartment. Science (Wash. DC). 218:477-478.

20. Bonner-Weir, S., and L. Orci. 1982. New perspectives on the microvasculature of the islets of Langerhans in the rat. Diabetes. 31: 883-889.

21. Schebalin, M., S. I. Said, and G. M. Makhlouf. 1977. Stimulation of insulin and glucagon secretion by vasoactive intestinal peptide. $\mathrm{Am}$. J. Physiol. 232:E197-E200.

22. Moody, A. J., L. Thim, and I. Valverde. 1984. The isolation and sequence of human gastric inhibitory peptide (GIP). FEBS (Fed. Eur. Biochem. Soc.) Lett. 172:142-148.

23. Pandol, S. J., H. Seifert, M. W. Thomas, J. Rivier, and W. Vale. 1984. Growth hormone-releasing factor stimulates pancreatic enzyme secretion. Science (Wash. DC). 225:326-328.

24. Schmidt, W. E., E. G. Siegel, and W. Creutzfeld. 1985. Glucagonlike peptide-1 but not glucagon-like peptide-2 stimulates insulin release from isolated rat pancreatic islets. Diabetologia. 28:704-707.

25. Orskov, C., J. J. Holst, S. Knuhtsen, F. G. A. Baldissera, S. S. Poulsen, and O. V. Nielsen. 1986. Glucagon-like peptides GLP-1 and GLP-2, predicted products of the glucagon gene, are secreted separately from pig small intestine but not pancreas. Endocrinology. 119:14671475. 